\title{
"BEHOLD HOW THAMES DOTH SMOOTH HER SILVER WAVES! [...] PROUD TO RECEIVE YOU TO HER WATERY BED": AN INTRODUCTION TO RACHEL JEVON'S STUART POETRY
}

\author{
Juan de Dios Torralbo Caballero
}

Universidad de Córdoba

\begin{abstract}
This work investigates the legacy of Rachel Jevon, specifically the poem Exultationis Carmen: To the Kings Most Excellent Majesty upon his Most Desired Return (1660), studying how it is constructed and how it contributes to the historical dialogue of its time. First, the literature of the Stuart Successions is addressed to contextualise the poem, along with a brief biographical note on its author, born in Worcester. Second, the Virgilian echo ("Fourth Eclogue") that Jevon's poem contains is noted. Third, the essay focuses on some fragments of the poem, segmented through historical milestones of the era, to analyse their content, educe their authorial dimension, and link them thematically to the different episodes of the history of England that transpired from 1649 to 1660.
\end{abstract}

Keywords: Rachel Jevon, Stuart Literature, Exultationis Carmen, Commonwealth, Restoration, Charles II.

\section{Resumen}

Este trabajo investiga el legado de Rachel Jevon, concretamente el poema Exultationis Carmen: To the Kings Most Excellent Majesty upon his Most Desired Return (1660), estudiando cómo se integra en el diálogo histórico de la época y cómo contribuye a éste. En primer lugar, se aborda la literatura de la monarquía de los Estuardo para contextualizar el poema, añadiendo una breve nota biográfica sobre su autora, nacida en Worcester. En segundo lugar, se infiere el eco virgiliano ("Égloga IV") que contiene el poema de Jevon. Seguidamente, el ensayo se centra en algunos fragmentos del poema, los cuales se segmentan a través de los hitos históricos de la época para analizar su contenido, colegir la dimensión autorial del mismo y vincularlo temáticamente con los diferentes episodios de la historia de Inglaterra acaecidos desde 1649 hasta 1660 .

Palabras clave: Rachel Jevon, literatura Estuardo, Exultationis Carmen, República, Restauracióm, Carlos II. 


\section{Introduction}

This work explores the sole work of Rachel Jevon, her eulogy to the King, printed in London in 1660. The poem consists of 192 verses and was published in both Latin and English in the same year. The Latin title is Carmen Thriambeutikon, while the English one is Exultationis Carmen: To the Kings Most Excellent Majesty upon his Most Desired Return.

First, some observations on the literature of the Stuart Successions are made, in order to contextualise the writer's political and laudatory literature. Next, after introducing Jevon's legacy, selected segments of the poem are studied, applying a reading that investigates its society and the historical features reflected in the literary text. We are not aware of the existence of any studies similar to this one.

The uniqueness and value of Rachel Jevon in this publication have recently been pointed out by Margaret J.M. Ezell (117), and Andrew McRae and John West (150), experts in 17th-century literature. Brenda M. Hosington (90) also studied Jevon's odes, relating them to eulogistic and funerary literature written by women. Previously, Carol Barash (43) wrote that "Jevon elides her political and poetic subjectivities into the expressive realm of emotion, claiming it is not she who writes the poem, but her 'exultation"”. Previously, Elaine Hobby (19) had already stated that Jevon's poem "was not the naive outpouring that it might at first appear"; and that it entailed a "planned strategy of publicising her learning, loyalism and humility", as two years later she "made a personal [...] petition to the king for "the place of one of the meanest servants about the queen"”.

\section{Literature of the Stuart Successions}

In Andrew McRae and John West's recently published Literature of the Stuart Successions. An Anthology, both professors situate and sequence this type of writing in accordance with key dates marking historical milestones over the course of the 17th century. Hence, the book consists of six parts: 1603,1625 , 1653 and 1658, 1660 and 1702. The section devoted to the Restoration of the Monarchy ("Part IV: 1660") contains eight clearly ordered sections. First, "The Declaration of Breda (1660)"; second, "John Milton, from The Ready and Easy Way to Establish a Free Commonwealth (1660)"; third, "Samuel Pepys, from his diary (25 May 1660)"; fourth, "Martin Parker, The King Enjoys his Own Again. 
To be Joyfully Sung, with its Own Proper Tune (c. 1660)"; fifth, "John Dryden, Astraea Redux. A Poem on the Happy Restoration and Return of his Sacred Majesty Charles the Second (1660)"; sixth, "Rachel Jevon, Exultationis Carmen: To The Kings Most Excellent Majesty upon his Most Desired Return (1660)"; seventh, "John Crouch, The Muses' Joy for the Happy Arrival and Recovery of that Weeping Vine Henrietta-Maria, the Most Illustrious Queen-Mother, and her Royal Branches (1660)"; and eighth, "Edmund Waller, A Poem on St James's Park as Lately Improved by His Majesty (1661)".

Among the eight works included, one of female authorship stands out: that by Rachel Jevon, addressed in this article. Jevon is noteworthy as the only woman (McRae and West 179) who wrote and published a panegyric to the Restoration of the Monarchy in the year 1660. Brenda H. Hosington (81-82) addressed the question of the "Englishwomen's Latin writings" and concluded that they dedicated their efforts to laudatory, eulogistic and funerary poetry. Hosington (98) goes back to 1549, when the daughters of the Duke of Somerset (Anne, Margaret and Jane) composed an elegy, Hecatidistichon, after the death of Marguerite de Navarre, which was published in Paris in 1550. She adds the examples of Elizabeth Jane Weston (Poëmata, 1602; Parthenicôn, 1606) and Bathsua Reginald, who published 15 poems in Musa Virginea (1616) dedicated to James I of England. Carol Barash (42) characterised this writing as "a type of political action $[\ldots]$ to reinforce royalist political sympathies".

\section{Rachel Jevon}

Rachel Jevon was born in 1627, the daughter of a clergyman (a rector) whose ministry was in the Diocese of Worcester. The writer's historical legacy is scant. According to Joseph Crowley (393), the name of Rachel Jevon is recorded in just four documents: the Latin poem celebrating the return of Charles II, its self-translation into English, a parish record with her birth certificate in Worcestershire (Broom), and two requests to the King for "the place of one of the meanest servants about the Queen" and for "the place of Rocker to the Queen" (qtd. in Crowley 393), dated from 1662.

The poem was published in Latin and in English. In this regard, Elaine Hobby (19) states that "it was very rare for women to be taught Latin in the period, and almost unknown for them to publish in the language". According to the annotations made in the title, the writer herself gave the poem to the King on August 16, 1660. Brenda M. Hosington (90) deduced that "the odes share many lines, although one is not a translation of the other" adding that "an interesting 
difference between the English and Latin versions [...] occurs. In the former, as the king is restored, so Jevon's "dead Muse" is drawn from her urn".

\section{Title and preliminary quote: "iam redit et Virgo, redeunt Saturnia regna"}

The poem consists of 192 verses, ${ }^{1}$ preceded by this quote in Latin: "En rediit", celebrating the return of a golden age, "the return of Saturn's reign". The use of the theme in imperial panegyrics is modelled on Virgil's "Fourth Eclogue" (Gatz 138-9).

The title is, per se, descriptive of the historical juncture that contextualises and fuels it (Exultationis Carmen: To the Kings Most Excellent Majesty upon his Most Desired Return), which is supported by the explicit quote from "Carolus" and, more specifically, the verbal reference "En rediit", which, through the verb "redit", clarifies the meaning of the king's return from the beginning. The Virgilian eclogue is known as the messianic eclogue. The Latin reference is a recreation produced by Jevon of the sixth verse of Virgil's "Eclogue IV", which reads: "iam redit et Virgo, redeunt Saturnia regna"; that is, "Now returns the Virgin, returns the reign of Saturn". The first seven verses of the 63 that Virgil (9) wrote are:

Sicelides Musae, paulo maiora canamus!

Non omnis arbusta iuvant humilesque myricae;

si canimus silvas, silvae sint consule dignae.

Ultima Cumaei venit iam carminis aetas;

magnus ab integro saeclorum nascitur ordo:

iam redit et Virgo, redeunt Saturnia regna;

iam nova progenies caelo demittitur alto.

The Virgilian source is considered a political text whose characteristics suggest that it was apt and capable of inspiring Rachel Jevon's celebratory poem (Nisbet 161, Hosington 82). The seventh verse praises the arrival in general: "now a new generation descends from heaven". This influence can also be appreciated in John Dryden's Astraea Redux (1660), which may be translated as Justice Restored and whose header includes the sixth verse of the aforementioned Virgilian eclogue: "Iam Redit \& Virgo, Redeunt Saturnia Regna”, which corroborates its rereading and its application (Burrow 28) in English literature to define political circumstances (Martindale 117). The

\footnotetext{
${ }^{1}$ The primary text is cited using the edition by Andrew McRae and John West (179-185), indicating in each case the corresponding verse number(s).
} 
Virgilian source makes it possible to "add a contemporary political resonance to compliment a ruler" (Liversidge 95).

\section{Memory of Charles I: "The living image of our martyred King"}

The next verses begin by welcoming the restored King and presenting a sequence of glorifications of the monarch, stressing the recognition of his ancestors and explicitly referring to and exalting his father Charles I. According to the historian Ian Mortimer (3):

In April of 1646, after a string of military setbacks, the King seeks refuge among his Scottish subjects. A few months later, the Scots give him up and send him as a prisoner to the English Parliament. After a brief second civil war in 1648, which ends in defeat for the royalists, Charles is tried for high treason: he is found guilty and beheaded at Whitehall on 30 January 1646. A few days later the monarchy and the House of Lords are abolished. England, Wales, Scotland and Ireland are collectively declared a republic - a "Commonwealth and Free State" and Parliament formally confirms itself as the source of all just power in the British Isles.

The king, therefore, was beheaded on the scaffold at Whitehall on the morning of Tuesday, January 30, 1649, by the Republican Puritans led by Oliver Cromwell. This historical fact is injected into the poem in the following way:

Welcome mild Caesar, born of heavenly race,

A branch most worthy of your stock and place,

The splendour of your ancestors, whose star

Long since out-shined the Golden Phoebus far;

The living image of our martyred King,

For us his people freely suffering;

Sprung from the rose and flower-de-luce most fair,

The spacious world ne'er boasted such an heir. (13-20)

\section{The Battle of Worcester, September 3, 1651: "Your strange escape from Worcester's bloody fight"}

The writer evokes the fight that raged between the Royalist and Republican armies, particularly at the Battle of Worcester, in which the troops led by Oliver Cromwell defeated the King's army: 
Could ever rebels act a part so vile?

Hence, hence sad sorrows, and all past annoys,

Let nought approach you but triumphant joys;

And let us remember now with delight

Your strange escape from Worcester's bloody fight,

Through thundering troops of armed foes, whose strife

Was to bereave you of your sacred life.

Where many thousand Britains spilled their blood,

Weltering in gore, for King and country's good: (38-46)

The Republican faction is described pejoratively as the "rebels", and their actions condemned with the reproachful adjective phrase "so vile". Cromwell's troops are then defined negatively, as the enemy: "thundering troops of armed foes". The poem evokes the contrast between a set of dire and turbulent years, and other years of peace and hope. The faction with which the writer identifies herself, and the one she glorifies, is included through the metonym (totum pro parte) in the phrase "many thousand Britains", which emphasises the number of the King's followers, at the same time alluding to the bloodshed and suffering inflicted on the monarch's army, which is underlined in the following verse ("for King and country's good") through the adverbial of manner ("Weltering in gore") and, principally, in the description of the side: "for King and country's good".

\section{The exile: "Then wandering through inhospitable lands"}

The next fragment portrays the fleeing King wandering through inhospitable lands and points out the fact that he was exiled from his country ("[...] banished from every part"), such that the world (another personification to denote the anomalous situation) "[...] stands / To see him [...]". The adversative prayer stands out in the middle of verse 70, highlighting the King's faith, alluding to his ancestors, and then contrasting his affable character ("charms", "love" and "piety") and kindliness in the face of the arms, revealing a mysterious aspect (Nisbet 173), which is also present in the Virgilian eglogue that inspired Jevon's poem:

Then wandering through inhospitable lands.

Still seeking rest, the world amazed stands

To see him banished from every part

Of its great orb, yet from his faith not start;

Nor to regain his father's rights would be,

From th'ancient worship of his fathers flee, 
For every kingdom he subdued by charms,

Of love and piety, more strong than arms. (67-74)

\section{The exiled king arrives in France: "France [...] receives this deity of peace"}

France is introduced into the text through a broad personification that contains both negative and positive attributes. Firstly, the country is described as if it were a person, whose hair is "[...] dishevelled, torn and sad"; that is, by means of three adjectives denoting a state of distress. France's personification also includes a description of the country as dressed in the bloody garments (the adjective stresses their warlike nature, through the chromatic image of blood it conveys) of civil war. Rachel Jevon integrates into the text the uprisings known as La Fronde, which took place during the regency of Anne of Austria and the minority of Louis XIV. Charles II went into exile in France from October 1651 to July 1654 ; these wars took place from 1648 to 1653 :

France with her hair dishevelled, torn and sad,

With bloody robes of civil war beclad,

With joy receives this deity of peace, (75-77)

France is also portrayed as having a generous nature, as (note that the adverbial phrase is placed before the verb) it receives him "With joy [...]" The object, the arriving King, is described by the circumlocution "this deity of peace", whose semantic purpose is to transmit the monarch's divine character and its peaceful implications through the genitive "[...] of peace".

\section{Recalling the King: "[...] Druina [...] recalls him to his native grove"}

The central part of the poem symbolically contains the call made by the English country to its exiled heir. The historical reference corresponds to May 1, 1660 when all the Members of Parliament decided to invite the crown prince to the throne (Mortimer 5). In this allegorical language, Druina signifies England ${ }^{2}$ :

At length Druina ravished with love,

Humbly recalls him to his native grove,

In peace to triumph, and to reign to lord

O'er hearts subdued by love, not by the sword. (91-94)

\footnotetext{
${ }^{2}$ McRae and West (183) explain that this correspondence between Britain and Druina "was not uncommon in the mid-seventeenth century". In the book by James Howell (Dendrology, Dodona's Grove, 1640) "the forest of Druina is ruled over by the royal oak".
} 
In addition, Jevon communicates that the king's return, the inauguration of the new era, is achieved in peace, highlighting the semantic field of love and triumph ("peace", "triumph", "reign", "hearts", "love") and pointing out, by means of the rhetorical figure of the extenuatio, attenuatio, or litotes, the absence of war in the Restoration: "not by the sword" (94).

The following fragment begins with a personification of England calling out for the presence of its King. It is the third time that the adverb "humbly" appears in the poem: first it was to define the writer's offer to the restored monarch (92), the second was to describe how Britain called out to its exiled heir (96), and in this new case "humbly" appears to underscore this same nuance of moderation and obedience with which the people plead for the return of the new king. The nation is described as "Three widowed kingdoms their espoused king", while Charles is referred to as their husband:

His native country faint and languishing,

Humbly implores the presence of her king:

Lo how the late revolted sea obeys,

How gladly it the billows prostrate lays

Before your royal navy, proud to bring

Three widowed kingdoms their espoused king! (95-100)

Natural elements, the sea and the clouds, accompany the King's arrival. The sea, also personified, is described as obedient, in contrast to its previously tumultuous state ("[...] late revolted sea [...]"). In the same way, the mass of clouds at sea also dissolves, as the royal navy is "[...] proud to bring" the king, thereby healing the pain all across England.

\section{Arrival: "The fates are kind; conduct you to the shore"}

Throughout the poem, Nature is described as a force participating in and favourably reflecting the text's central events. The writer points out the efforts of the winds to produce propitious gales (a kind of oxymoron), such that they propel the "blessed" ships, which are also portrayed as having a sacred and celestial halo. With regard to the ships, Jevon notes that they are the property of the heir, by means of the possessive adjective "your":

How do the winds contend, the spreading sails

Of your blessed ships, to fill with prosperous gales;

The fates are kind; conduct you to the shore,

To welcome you the thundering cannons roar; (101-104) 
The poem states that "The fates are kind [...]", thereby evoking the Moiras ( $\mu$ oĩ $\alpha$, destiny, Greek goddesses) or the Fates (Roman goddesses), and suggesting the destiny of man; in this case, the destiny of the exile. In this way, he is "[...] conduct[ed] to the shore". Upon his arrival, according to the poem, the cannons (again, through the rhetorical figure of personification) welcome him. The "cannons" are premodified by a denominal adjective, which in this case does not contribute any extra meaning to the noun, whose function is to reinforce the noise produced by the "cannons".

\section{Reception: "With you to earth Astraea fair is come"}

The people who turn out to meet them are presented with reference to a scale of hierarchy and possession, as the subject of the following sentence is "Your ravished subjects [...]". Their joy is underscored by the hyperbaton, as the adjective "overjoyed" appears as a postmodifier of "subjects". The verb phrase "do stand" then enhances this sense of fruition and happiness, precisely thanks to the emphatic use of the verb "do" before the main verb "stand". The crowd that rejoices awaiting the crown prince harbours a purpose clearly expressed in the poem, through the subordinate adverbial clause of purpose "To see the stranger (Peace) with you to land". In this way peace is materialised and concretised, as it can be observed and seen, and is presented as an inherent attribute of the future King:

Your ravished subjects overjoyed do stand,

To see the stranger (Peace) with you to land,

With you to earth Astraea fair is come,

And golden times in iron ages room: (105-108)

The poet portrays the arrival of justice to English shores, precisely when

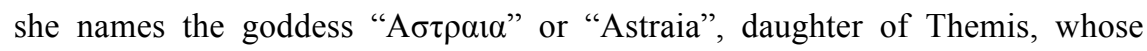
postmodifier (hyperbaton) emphasises her role as the goddess of justice on earth. This meaning is related to and linked to "The Declaration of Breda", signed on April 4, 1660 in that city (presented in both Houses of Parliament on May 1) as well as its practical application in the "Act of Oblivion" ("An Act of Free and General Pardon, Indemnity, and Oblivion"). The declaration and subsequent legislation demonstrate the lenient and conciliatory nature of the new era, although it established that the crimes against Charles I were not pardoned.

The writer explicitly refers to the shift from one era to another through her references to "iron ages" giving way to "golden times", and by means of two patterns that appear in the poem consecutively and in a structurally parallel way (premodifier and noun), with the verb (hyperbaton) occupying the final position 
of the line: "And golden times in iron ages room". The categorical and apodictic value of this verse is further reinforced by the initial conjunction "and", which presents the idea as a conclusion, as if it were a syllogism.

Diarists of the time John Evelyn and Samuel Pepys left written testimonies documenting how the city rejoiced. Specifically, in the Diary of Pepys we read of a king, considered a New Augustus, who arrives in Dover, the country joyously celebrating:

I [Pepys] went, and Mr Mansell and one of the Kings footmen [...] went in a boat by ourselves; and so got on shore when the King did, who was received by Generall Monke with all imaginable love and respect at his entrance upon the land at Dover. Infinite crowd of people and the gallantry of the horsemen, citizens, and noblemen of all sorts. The Mayor of the town came [...]. (Pepys 150)

\section{A formal song celebrating the return of the monarchy: "Proud to receive you to her watery bed"}

The following fragment is a song within the general poem and directly addresses the king, by means of several verbs in the infinitive at the beginning of the first and third verses ("Behold", "Mark"). The writer, the lyrical subject, explains to the king how the river (personification) calms the waves and is happy to receive him, humanised by means of the direct object "your gilded bark". It is significant that the waves are described as silver, and the king's boat as gold, again establishing a hierarchy and a relationship of superiority between the monarch and the rest of nature, in this case animated and humanised. Another notable aspect to be considered is the use of the simple present, endowing the action with a timeless and eternal meaning:

Behold how Thames doth smooth her silver waves!

How gladly she, your gilded bark receives;

Mark how the courteous stream her arms doth spread,

Proud to receive you to her watery bed. (113-116)

The poem features erotic symbolism, ${ }^{3}$ establishing a relationship between the River Thames, which is pronominalised in the feminine ("her silver waves", "she", "her arms"), and the king, directly referred to with these terms: "your gilded bark", "you" as an object pronoun $(116,119)$, "your presence" and "you" as a subject pronoun $(124,125)$. These semantics are supported not only through

\footnotetext{
${ }^{3}$ Carol Barash (43) alludes to "a similar cluster of sexual images" in the manuscript poem, "Upon his Majesties most happy restoration to his Royall Throne in Brittaine".
} 
the personification of the current, embracing him, but also the locative reference "her watery bed".

A comparison between the past and the present is then suggested, the "old" and the new, the bad and the good, contrastively denoted by "tyrants" who have "torn the city" and "beauteous youth", temporarily marked by the verb tenses endowing the past ("torn") with its finished and completed aspect, in contrast to the simple present ("adorn") which denotes the duration of the action and an eye on the future. The presence of the king is highlighted by the adjective "ravished", this being the third time that it appears in the poem (lines 91 and 105) to describe the people's enthusiasm. This verse, again, syntactically contains a hyperbaton that spotlights the complement of the verb "gaze" in order to emphasise the receiver, whom the population beholds with delight:

The old metropolis by tyrants torn,

Your presence doth with beauteous youth adorn.

On you how do the ravished people gaze? (117-119)

The following sequence contains elements that conceptualise the sound made by the crowd receiving and celebrating the return of the monarchy, specifically through the alliteration of fricative and plosive phonemes in the phrase "the thronging troops" and through the verbs in the next two verses: "shout" and "ring", which accentuate the Majesty's reception, as even the triumphant streets "ring again". The adverb "again", which reappears three verses later (125), helps to underscore the idea of a return, one to the joy and happiness before the Regicide, the Civil Wars and the Interregnum:

How do the thronging troops all in amaze

Shout loud for joy, their King to entertain,

How do their streets with triumphs ring again. (120-122)

The poem portrays another relationship between the king and the people, denoted first through the rejoicing of the personified streets (122), and the explicit reference to "we" as the subject in the syntactically anomalous sentence "You we adore", and the explicit reference to "us" $(124,125)$ as an object in the second part of the same verse and in the next. The vertical relationship between the king and the people is established semantically through the verb "adore" and the adjective "poor", which premodifies "mortals" (124). In this way the figure of the monarch is absolutised and deified, the monarch's divine meaning being contrasted with the mortal nature of the rest of the people:

Great Charles, terrestrial god, offspring of heaven,

You we adore, to us poor mortals given,

That you (our life) may quicken us again, (123-125) 
The absolutisation of the king appears in the previous verse (123) through three noun phrases written consecutively, and through the asyndeton whose illocutionary and perlocutionary effect is to offer an ample list of positive attributes of Charles II, thereby generating a rigorous cumulative effect in the enumeration. The meaning of the three phrases is established in crescendo, as he is first called "Great Charles"; secondly, "terrestrial god"; and, finally, son "of heaven". The third phrase ("offspring of heaven") stands out compared to the other two previous ones because its morphological structure (substantive and genitive) breaks the parallel structure that the first two maintain (adjective as premodifier and substantive as head of the noun phrase). In this way, not only is the fluid and consecutive enumeration accentuated, but also the divine nature conferred on the protagonist of the poem.

The poem contains a rhetoric of persuasion, similar to that achieved by John Donne in his poem "The Flea" (Donne 47) which begins in media res and also makes use of the imperative in its first verse: "Mark but this flea, and mark in this" (1), in this case conveying the erotic theme of the fusion between the lovers' blood, following Aristotelian postulates. Recalling the abrupt beginning of Donne's poem, published posthumously in 1633, is inevitable and its erotic content, which a seasoned reader during Rachel Jevon's time would probably have in mind.

\section{The monarch as the Saviour of the people: "With peaceful olive in his sacred hand"}

The references and the semantics of the poem evoke plain imagery, mythological references and, finally, religious symbology conceptualising the return of the monarchy through the arrival of the Saviour God himself. A parallel is obvious when Charles is introduced as a Christ-like figure, entering Jerusalem, carrying an olive branch, transmitting the semantics of peace and the sacred nature of the protagonist:

Lo lovely Charles with dove-like galles soul, (Coming to th'ark of his blood deluged land, With peaceful olive in his sacred hand)

Espoused is to Albion dyed in Gore

And to her princely beauty doth restore; (155-159)

Other images, such as the portrayal of Charles as a dove, or as a wife, proceeding from the book of "Genesis" (8:11) and "Songs of Songs" (6:9), denote the symbiosis between Christ and his Church, and Charles and his people. 
In the final verses of the poem are phrases such as "Celestial Charles" (189), the text concluding in this way:

Celestial Charles triumphantly ascent

T'enjoy the heavens in bliss without all end.

Glory to God alone,

Thrice blessed three in one. (189-192)

The two final verses present an evident intertextuality with the poem "L'Envoy" (McRae and West 185) by the devotional poet George Herbert (239), where we also find these verses at the close of the metaphysical poem: "Blessed be God alone, / Thrice Blessed Three in One" (17-18). Herbert, thus, also included the Trinitarian doxology in a poem addressing Jesus. In this way Jevon reiterates the correlation between Charles and the Saviour, positioning her text in the tradition of English religious poetry.

It is remarkable and significant that the religious semantic field emerges in the final section of the poem, precisely when the king (defeated in war, exiled, beseeched, returned and restored) has made his triumphal entry into his country; that is, once the achievement entailed by the work's thematic centrepiece has been realised. In this way Rachel Jevon elevates and sublimates the king through this Biblical language, conveying the benefits of the monarchy's Restoration for her country and her people.

\section{Conclusion}

The poem reflects the historical events of its era, at times condemning them, such as in the case of the beheading of Charles I, the Civil War, and the flight and exile of Charles II; and other times documenting and praising them, in its allusions to the call for, welcoming of and, in general, return of the exiled king and the Restoration of the monarchy.

As suggested, the abundant use of hyperbaton is owing to the air of uneasiness described, generating an atmosphere echoing the doleful events and reflecting the painful turbulence of the time for the Royalists, as a result of the regicide, the Civil War, and Cromwell's theocracy. In contrast, Rachel Jevon uses other devices to achieve the opposite effect when the semantics address the desire and call for the monarchy and the moment of its restoration. In this regard, the extensive use of personification (for example, by means of an animated Nature, which joyfully receives it) contributes to the generation of an atmosphere amenable to the king's return. In the same way, the use of alliteration and euphemisms auditorily stress the jubilation of the Restoration. 
The poem relates the king's return to that of a peaceful, just and abundant golden age, which allows us to infer that Rachel Jevon's work contains an echo of Virgil's "Eclogue IV", which became the source of numerous imperial panegyrics, as evidenced by the Drydenian panegyric Astraea Redux. In fact, Jevon's poem features, in its heading, a quote from the aforementioned Latin eclogue. During Jevon's time Virgil's work was known in England, thanks to the revival of interest in classical works and the translations of it.

The text is a clear echo of its historical time, integrated into the historical dialogue of the era through the inclusion of different episodes that took place in the period between Charles I's beheading and his son's return from exile in several countries, and was received with much joy and exultation. This poem faithfully reflects the "Royalist print culture" (Peters 2017), becoming a source of knowledge and historical pedagogy for both readers of its time and today.

Rachel Jevon's poem evidences her able handling of references to the historical developments and figures of her time. Likewise, the verses reveal her education and wide-ranging knowledge of classical literature and mythology, the Bible, and the English literary tradition.

\section{WORKS CITED}

Barash, Carol. English Women's Poetry, 1649-1714. Politics. Community, and Linguistic Authority. Oxford: Clarendon Press, 1996.

Burrow, Colin. "Virgil in English Translation." The Cambridge Companion to Virgil. Ed. Charles Martindale. Cambridge: Cambridge University Press, (1997) 2011. 21-37.

Crowley, Joseph. "Rachel Jevon, Exultationis Carmen (1660)." Reading Early Modern Women. An Anthology of Texts in Manuscript and Print 1550-1700. Eds. Helen Ostovick and Elizabeth Sauer. New York and London: Routledge, 2004. 393-394.

Donne, John. The Complete English Poems of John Donne. Ed. C. A. Patrides. London: Dent \& Sons (1985) 1988.

Ezell, Margaret J. M. The Oxford English Literary History. Volume 5: 1645 1714. The Later Seventeenth Century. Oxford: Oxford University Press. 2017.

Gatz, B. Wetalter, goldene Zeit und sinnverwandle Vorstellungen. Hildesheim: Olms. 1967. 
Herbert, George. The Temple: Sacred Poems and Private Ejaculations. Pickering: London, 1838.

Hobby, Elaine. Virtue of Necessity. English Women's Writing 1649-88. London: Virago Press, 1988.

Hosington, Brenda M. “"The Well-Wrought Verses of An Unknown Bard:' Renaissance English Women Latin Poetry of Praise and Lament." Acta Conventus Neo-Latini Upsaliensis (Proceeding of the Fourteenth International Congress of Neolatin Studies). Ed. Astrid Steiner Weber. Leiden and Boston: Brill, 2012. 81-104.

Jevon, Rachel. "Exultationis Carmen: to the Kings Most Excellent Majesty upon his Most Desired Return (1660)." Literature of the Stuart Successions. Eds. Andrew McRae \& John West. Manchester: Manchester University Press, 2017. 179-185.

Liversidge, M. J. H. "Virgil in Art." The Cambridge Companion to Virgil. Ed. Charles Martindale. Cambridge: Cambridge University Press, (1997) 2011. 91-103.

Martindale, Charles. "Green Politics: The Eclogues." The Cambridge Companion to Virgil. Ed. Charles Martindale. Cambridge: Cambridge University Press, (1997) 2011. 107-124.

McRae, Andrew and John West. Literature of the Stuart Successions, Manchester: Manchester University Press, 2017.

Mortimer, Ian. The Time Traveller's Guide to Restoration Britain. A Handbook for Visitors to the Seventeenth Century: 1660-1700. New York and London: Pegasus Books, 2017.

Nisbet, R. G. M. "Virgil's Fourth Eclogue: Easterners and Westerners." Oxford Readings in Classical Studies. Vergil's Eclogues. Ed. Katharina Volk. Oxford: Oxford University Press, 2008. 155-188.

Pepys, Samuel. The Diary of Samuel Pepys. Vol I. Ed. Henry B. Weatley. New York: MacMillan, 1892.

Peters, Erin. Commemoration and Oblivion in Royalist Print Culture, 16581667. New York: Palgrave, 2017. https://doi.org/10.1007/978-3-31950475-9

Virgil. Bucolics, Aeneid, and Georgics of Virgil. Ed. J. B. Greenough. Boston: Ginn \& Co, 1900.

Vergili Maronis, P. "Eclogue IV.” Opera. Ed. Sir Roger Aubrey Baskerville Mynors. Oxford: Oxford University Press, 1986. 9-11. 
